\title{
Commercialisation of water supply in Zimbabwe and its effects on the poor: A working framework
}

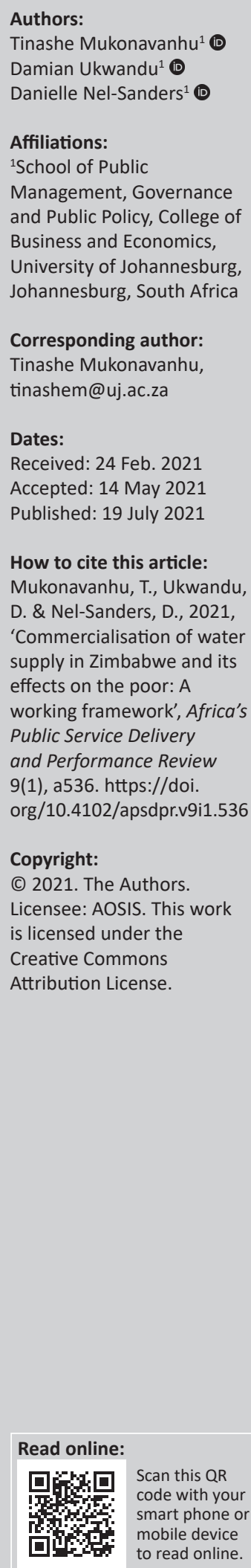

Background: Neoliberalism favours the existence of free markets with limited government interference as the best way to conduct business. A feasibility study is necessary regarding the practicality of the application of neoliberalist policies in Zimbabwe's water sector. This is important because there has been a lack of water in urban and rural areas of Zimbabwe even before the COVID-19 era.

Aim: The objective of this study was to investigate the feasibility of the commercialisation of water in Zimbabwe.

Setting: The formation of the state-owned Zimbabwe National Water Authority signified a move towards the solidification of the commercialisation of the water sector in Zimbabwe, based in part on neoliberal principles.

Methods: This study is a conceptual study, involving the review of various sources of literature to identify trends in the commercialisation of Zimbabwe's water sector. This study is descriptive in nature and involves the use of secondary data gathered from various publications. This study also makes use of a case study approach.

Results: The findings of this study show that the commercialisation of the water sector in Zimbabwe is practical to a certain extent; however, it needs to be performed in a way that acknowledges existing strengths and weaknesses with continuous monitoring and evaluation taking place.

Conclusion: While commercialisation is a necessary tool to incentivising economic water usage and generate revenue, there is a need to ensure that those who cannot afford to pay for water in Zimbabwe are safeguarded in order to guarantee their access to basic water, which is their human right.

Keywords: neoliberalism; commercialisation; water; government; Zimbabwe.

\section{Introduction}

Over the last 10 years, several African states have implemented new innovations or have just begun restructuring their water sectors. This process is crucial especially in light of climate change, growing global populations and increased levels of water pollution. The water sector reforms that have been put in place in African states have to a larger extent come because of increasing calls for change from world states. The pressure that has been applied on global governments is aimed at pushing forward the need to introduce sustainable water management techniques.

The United Nations Convention on Sustainable Development - the Earth Summit - that took place in Rio de Janeiro in 1992 has, for example, led to increases in the policing of international water management practices (Makurira \& Mugumo 2006:167).

Present-day water management practices place great emphasis on the vitality of water management approaches that consider the environment as an authentic user with its own rights. More focus has been directed towards pollution prevention in new water management drives, with more emphasis being placed on the need to treat water as an economic good that has value and must be paid for by users. Greater efforts have also been directed towards enabling enhanced local stakeholder involvement in water management initiatives by devolving management functions to catchment and watershed levels. Ghana, Zimbabwe, South Africa, Zambia, Swaziland, Malawi, Uganda, Kenya and Tanzania are typical examples of African states that have implemented new improvisations in their water sectors (Makurira \& Mugumo 2006:167). The aim of this article is to investigate the feasibility of the commercialisation of water in 
Zimbabwe and to make recommendations as to the best means to balance sustainable water usage in Zimbabwe with the needs of the poor.

\section{Methodology}

This study centres on desktop analysis. The study is also descriptive in nature, utilising secondary data gathered from various sources such as articles, journals and conference papers, amongst others. Secondary data sources in this study are analysed using unobtrusive research techniques, with the analysis of various secondary sources linked to the aim of this study. Conceptual and comparative analyses of secondary data were utilised in the study.

Conceptual analysis was implemented by means of differentiating between interpretations of terms, as well as the understandings that such terms convey. Furthermore, a comparative analysis was utilised to make comparisons of the impacts of the commercialisation of the water sector in Zimbabwe on the poor. A case study approach was also used to legitimise the study's conceptual validity, to lay the groundwork for sound means of arriving at new hypotheses, as well as to enable the thorough examination of such hypotheses and to allow for better understanding of the causes and effects of different factors at work in the context of commercialisation of the water sector and its effects on the poor.

\section{Neoliberalism defined}

According to Mathekganye, Van Heerden and Ukwandu (2019:43), neoliberalism came about as a result of the election to power of political leaders whose political views leaned more towards new right ideologies, particularly in the United States of America and Great Britain. There is no universal definition of neoliberalism, with different disciplines that gave rise to the term, such as politics, sociology and economics, all furnishing diverse definitions of neoliberalism. There are, however, some similarities between these varying and different definitions. For example, neoliberalism in some descriptions can be viewed as seeking to create new political systems and ideologies as opposed to reviving old ones (Davies 2014).

Neoliberalism is also defined as an ideology that is directed towards institutions and undertakings that are external to market boundaries (Mathekganye et al. 2019:44). In this sense, institutions that include, for example, tertiary education institutions, ordinary consumers, state entities and trade unions can be incorporated into market activities under neoliberalist concepts, via privatisation, deregulation, downsizing, unbundling, and so on. The intended goal is to re-organise these institutions so that they conform more to market-orientated characteristics, or to commercialise nonrenewable resources such as water (Burgin 2012; Gane 2013; Phillips-Fein 2009; Stedman-Jones 2012).

Thorsen and Lie (2007:2) give evidence that also supports the existence of pluralism in definitions of the term 'neoliberalism'.
In one of their definitions, Thorsen and Lie (2007:2) define neoliberalism as the revival of liberalism. Venugopal (2015:2) cites Crouch (2011:vii) who defines neoliberalism as the dominion over society by big business, whilst Venugopal (2015:2) describes neoliberalism as seeking to give back power to capitalist elites following the social and economic upheavals that occurred in the 1970s. Hölscher (2018:35) defines neoliberalism as the accumulation of power by business enterprises on an international scale, which enables them to dominate all aspects of life.

Mathekganye et al. (2019:46) cite Thorsen and Lie (2007), who formulated a definition of neoliberalism inspired by Blomgren's (1997) and Harvey's (2005) views and perspectives that more precisely explain what is happening in modern times. Thorsen and Lie (2007) describe neoliberalism as a varied pluralism of political views mostly featuring the belief that governments' sole justifiable role is to protect individual, commercial and libertarian rights, as well as the security of one's assets (Hayek 1979; Mises 1962; Nozick 1974). The neoliberal belief can thus be applied on an international scale with the protection of international trade and markets being regulated and the same phenomenon being applicable on a national scale in national markets.

\section{The relationship between neoliberalism and commercialisation}

Traditionally, neoliberal ideologies are traceable to the basic historical ideologies supporting non-interventionist financial and political theories supported by several authors and scholars in the past. Classically, liberalism is founded on the notion that people are free, and free to generate capital from commercial undertakings.

Neoliberalism emphasises the freedoms of liberated people, liberty and free will to make profit, and the right of individuals to go about their own business endeavours. Classic liberalism supports and promotes various notions that are associated with the commercialisation of enterprises such as the right to own private property, limited involvement of the government in markets, free trade, the right to amass wealth and the pursuit of personal prosperity (Hall 2011:13; Palley 2004).

According to Mathekganye et al. (2019:46), the idealism contained in neoliberalism is based on the notion that limited government interference in markets enhances business performance and capital enterprise both nationally and globally. This is based on the belief that free markets enable an environment that is optimal for business growth. Neoliberalism seeks to promote an environment characterised by, amongst others, the enhancement of the creativity of entrepreneurship, as well as enabling an environment in which the best enterprises thrive whilst underperforming businesses naturally die out under competition and are incorporated into better-performing enterprises. Such free markets would result in enhanced personal liberties and improved standards of living for all citizens, essentially resulting in the better allocation of resources in a state 
(Friedman 1962). These ideas advance the principles of free choice and consequence (Nozick 1974).

Neoliberal principles, in some cases, can be seen as promoting private sector-led economic growth at the expense of the promotion of social development and the rights of workers, as well as the rights of poor individuals. Neoliberalism is thus based on the thwarting of the social and political rights that citizens have by government, with government instead promoting the interests of private capital (Venugopal 2015:14). In underdeveloped and developing countries where capital is currently held in the hands of a small minority, neoliberal principles and ideologies need to be approached with caution. Neoliberalism tends to promote the interests of private capital at the expense of socialist goals. A state plagued with high levels of inequality and poverty cannot thrive democratically. Therefore, if not approached strategically, neoliberalism can thwart the interests of democracy.

Venugopal (2015:12) also asserts that neoliberalism as a theory places too much emphasis on economic development in an effort to implement remedies based on marketplace principles at the expense of other endeavours such as social and political ideals and goals. Neoliberalism can best be viewed as the total pursuit of economic advancement, the promotion of private capital, the denial of wealth redistribution and the thwarting of democratisation and social welfare. Neoliberalism as an ideology may very well lead to an increase in inequalities and wealth gaps in societies. Neoliberalism can also be viewed as promoting the empowerment of commercial entities whilst at the same time stripping away the power of government, labour and the masses.

\section{Water sector reforms in Zimbabwe}

Article 77(a) of the Constitution of Zimbabwe (Amendment No. 20 of 2013) ensures the right to safe and clean water. The inclusion of this right in the Constitution is evidence of Zimbabwe's commitment to water provision to all its citizens, which is in line with the human rights statutes that Zimbabwe promised to uphold, which are incorporated in the African Charter on the Rights of the Child, and the Protocol to the African Charter on the Rights of Women in Africa.

In 2010, the United Nations promulgated a law, stating that water and sanitation are both human rights. There are other laws that govern the use of water in Zimbabwe, including the Water Act of 1998 and the Zimbabwe National Water Authority (ZINWA) Act of 1998 (Government of Zimbabwe 1998a). Ensuring access to potable water is necessary for upholding several rights in Zimbabwe, such as the right to life, education, good health and sanitation. The Government of Zimbabwe is therefore obligated to provide clean and potable water to all citizens in Zimbabwe without bias, which means that water must be made available to all citizens regardless of their gender, race, status or language (Zimbabwe Lawyers for Human Rights 2015).
According to the Zimbabwe Lawyers for Human Rights (2015), the Zimbabwean government must:

- ensure that the right to water is promoted by refraining from hindering this right

- safeguard the right to water by avoiding any activity that may hinder people from benefitting from this right

- fulfil the right to access water by implementing measures that guarantee all people enjoy this right

- provide clean and potable water in Zimbabwe as a duty of the central government and local authorities.

In 1994, Zimbabwe underwent reforms in its water sector before any other country in the sub-Saharan region had ever embarked on their own water sector reforms. The water sector reforms in Zimbabwe in this period were as a direct result of two driving forces (Pazvakavambwa 2002). The first factor was that, internationally, there was a drive and thrust towards introducing more sustainable water management practices. The second factor was that the water legislation that was in existence in Zimbabwe at the time did not suit the democratic ambitions of the state. The existing legislation at the time did not allow, for example, the issuing of more water use rights, whereas the majority of the people in Zimbabwe had no access to a decent water supply. The existing legislation therefore stifled and limited the ability of most of Zimbabweans to have access to water. The 1976 Water Act, in particular, was a colonial law designed to safeguard the interests of the white minority, a minority which made up less than $1 \%$ of Zimbabwe's total citizenry of 13 million individuals (Manzungu 2002).

\section{Water legislation in Zimbabwe}

Water usage in Zimbabwe is administrated by the Water Act of 1998. Before the introduction of the Water Act of 1998, the Zimbabwean water sector was governed by the Water Act of 1976. The Water Act of 1976 enabled the ruling colonial regime to put all water use effectively under its firm control, based on a system designed by this same regime. The Water Act of 1976 'allowed' the citizens of Zimbabwe to utilise water resources, provided that the water they were exploiting was intended solely for domestic use. Beyond domestic use, any other use of water under the Water Act of 1976 was considered as commercial use, in which case a user had to obtain water use rights. Water rights could only be given to water users in Harare by the Water Court. The Water Court was located at the Administrative Court of Zimbabwe (Makurira \& Mugumo 2006:168).

\section{The Water Act of 1976 had several disadvantages:}

- There was no decentralisation in the issuing of water rights.

- Water rights were issued permanently to those who came first. As a result, no water rights would be allocated when water resources were fully assigned, despite whatever the need may have been.

- When there were water shortages, reallocation of water was a long and bureaucratic-laden process. 
- There was no evaluation of water rights, which meant that in the case of a right holder misusing their rights, the evaluation of these rights could only be made at the behest of the right holder.

- There was a lengthy process to acquire water rights. Those who had acquired water rights were not obligated to pay for them. They were also not required to contribute to water service provision.

- The Water Act of 1976 made no provisions for environmental protection or for safeguarding the quality of water.

- No attention was paid to groundwater. There was no regulation to control the usage of groundwater, nor the number of boreholes that could be drilled.

Several changes were made to the Water Act of 1976 as time went by, with global international pressure for changes in water management leading the push for changes to Zimbabwe's water legislation. As a result, the Water Act of 1976 was entirely reviewed, which led to its revocation in the enactment of the Water Act of 1998, which was aimed at aligning water management in Zimbabwe with international standards, as well as making it responsive to the needs of the general population of Zimbabwe (Makurira \& Mugumo 2006:168).

\section{The Water Act of 1998}

The Water Act of 1998 was promulgated into law following incorporation and participation of various shareholders. The Water Act of 1998 was based on principles of economic efficiency, environmental sustainability and equity of use.

The Water Act of 1998 is mainly characterised by the following:

- The replacement of water rights with water user permits. Water permits are given only for a specified time length, with their renewal made upon the analysis of the permit holders' efficient water usage, as well as the general availability of water.

- The first-come, first-served policy has been done away with.

- Private ownership of water has been abolished.

- A renewed perception of water from a holistic systematic perspective, that is, underground water and water found on the earth's surface are now considered as entities of a singular hydrological system.

- Organisations have been established to cater for and promote community involvement and participation in water management.

- The environment is now recognised as a user with its own rights and there is more emphasis on the use of more sustainable water management mechanisms.

- The polluter-pays principle is now in application, with more legislation being introduced that is geared towards pollution prevention.

According to Musemwa (2008:4), because of the effects of colonialism, the government of Zimbabwe at independence in 1980 was forced to deal with an unequal water allocation system that would remain in place until 1998. In 1998, two legislative laws were passed, namely, the Water Act and the ZINWA Act, which signalled an end to colonial water legislation. Under colonial rule in Zimbabwe, land was divided unequally, with white people enjoying the majority ownership of land, whereas black people were denied equal ownership to land. Black people were forced to reside in segregated reserves later known as communal lands where they had no ownership rights to land, could not buy or sell land and were therefore excluded from owning any water rights as well (Mbiba 2001).

The 1976 Water Act enforced the unequal ownership of land and water as well as enforced the unequal granting of rights to water access between people of white colour and nonwhite colour people in colonial Zimbabwe (eds. Von BendaBeckmann, Von Benda-Beckmann \& Griffiths 2005). This is a situation, unfortunately, that is still characteristic of land and water ownership in Zimbabwe in the present day, despite the Zimbabwean government having undertaken a robust and ambitious land reform programme that has ironically left the resettled communal farmers excluded from access to water in their new resettlements on previously white-owned commercial farms. The Zimbabwean government's dedication to creating equality in Zimbabwe's water sector after independence in 1980 by introducing laws that promote a fair and just system of water allocation was, however, testament to its pledge to achieving an equal and just society.

Zimbabwe is characterised by the frequent occurrence of droughts. One particular drought, which occurred in 1992, was so severe that it helped to propel the Government of Zimbabwe forward in repealing the colonial and racist 1976 Water Act. The 1992 drought and its severity convinced the Zimbabwean government that it could no longer delay in reforming Zimbabwe's water sector, and it led to the immediate revocation of the 1976 Water Act and the proclamation of the 1998 Water Act. As opposed to the Water Act of 1976, the Water Act of 1998 was based on the democratic management of water, with stakeholder involvement from all sectors in water usage decision-making processes. While the 1976 Water Act gave voting rights to water right holders only - with these voting rights being frequently granted to white commercial farmers - the Water Act of 1998 included all stakeholders, including collective farms selling produce on a small-scale and farms producing produce for sale on a large scale, mines, business interests, manufacturing and local governments (Musemwa 2008:8).

As part of ongoing water reforms in Zimbabwe, ZINWA was established by the Zimbabwean African National Union Patriotic Front (ZANU-PF) - led Zimbabwean state. Zimbabwe National Water Authority was tasked with the responsibility of assuming leadership in the water services sector in Zimbabwe, as well as the commercialisation of the water services sector in Zimbabwe. The commercialisation of water in Zimbabwe, seen as a steppingstone on the way to 
privatisation, has been attempted in many sectors, such as the clothing industry, the milk industry, telecommunications as well as in other public sectors amongst others. The establishment of ZINWA was born out of an aspiration to commercialise the management of water services in Zimbabwe, with Harare Water being used as a means to commercialise water supply (Manzungu et al. 2016:69).

Two basic changes that were introduced in the 1998 Water Act were fundamental to the commercialisation of the water services sector in Zimbabwe. Firstly, the 1998 Water Act introduced the policy of approaching water as an economic good, as opposed to water being treated as a social good, as had previously been the Zimbabwean government's position towards water. Secondly, the 1998 Water Act promoted the devolution of water service providers as well as the implementation of modern strategies of Integrated Water Resources Management. The 1998 Water Act made it legally binding for water users to pay for their water usage which was a step towards strengthening the commitment to abide by existing global economic reforms that were taking place at the time in other third-world countries. Pressure was being exerted by the global community for water sector reforms to be implemented in developing countries, specifically via the Economic Structural Adjustment Programme. This was also based in part on global pressures exerted by developed nations in third-world countries to move towards neoliberal policies and principles of governance (Musemwa 2008:9).

The user-pays principle was initially intended to apply to water used in business and industry and not to water used for personal household uses, which was deemed a commodity that could not be priced at the time in Zimbabwe. 'Primary water', as defined by the Water Act of 1998, means the reasonable usage of water for primary purposes, such as for fundamental household human requirements within the yard or compound of the water user. At some point in time, there was a departure from the philosophy of not pricing the usage of primary water in Zimbabwe. Even people who were not getting water were expected to pay fixed water tariffs by municipalities (Economic Consulting Associates Limited 2011:xi). The importance placed on the introduction of water charges resulted in the setting up of a new state entity in Zimbabwe, namely, ZINWA (Makurira \& Mugumo 2006:169).

According to Musemwa (2008:9), the ZINWA Act of 1998 was promulgated to provide the legislative framework for the establishment of ZINWA. The purpose of ZINWA was to take charge of the administration of all previously governmentowned dams and waterworks in urban and rural areas. The overall responsibility for the establishment and oversight of state water infrastructure was bestowed upon ZINWA. Zimbabwe National Water Authority was established to function based on the profit-making models of the private sector, characterised by charging consumers for water usage and the provision of clean water, and, in addition, the delivery of engineering expertise and skills, and in that way becoming financially self-reliant (Derman, Ferguson \& Gonese 2000).

\section{Implementation of commercialisation of Zimbabwe's water sector in view of sanctions and dwindling budgets}

According to Nyoni (2019:2), the economic sanctions in Zimbabwe have led to a collapse in the provision of sanitation services, coinciding with the endangerment of the ability of the state to provide clean water. Sanctions imposed on Zimbabwe have affected the ordinary Zimbabwean citizens negatively as they are mutually negatively impacted by the ineffective service delivery of not only water but also sanitation, education, health and food production (Hove \& Chingono 2013). Zimbabwe has experienced notable deterioration with regard to the extent to which its population can access clean water, as well as in the amount of water received per household as a result of economic sanctions. Water provided by city councils in all urban areas of Zimbabwe is not only consistently in short supply, but it is also often dirty to the extent that one can clearly see human excrement floating in the water.

The sanctions imposed on Zimbabwe have resulted in the crumbling of its economy. Trade embargos placed on Zimbabwe also played a major role in the destabilisation of the Zimbabwean economy (Kanyongo 2016:12). Economic sanctions in Zimbabwe led to the cutting of aid to Zimbabwe by international financial organisations (Will 2003). As sanctions were introduced in Zimbabwe, international financial organisations such as the International Monetary Fund, the World Bank and the African Development Bank have refused to lend money to Zimbabwe (Ogbonna 2017:32). As a result, Zimbabwe has not had the capital necessary to properly finance all its service sectors, including water services. This has had a largely negative effect on the quality of water services rendered in Zimbabwe.

According to Hove and Chingono (2013:12), social and economic turmoil came about because of the sanctions imposed on Zimbabwe. These economic and social upheavals included, amongst others, staggeringly high levels of inflation, the growth of informal trade, scarcity in the availability of basic goods, dire poverty, the emigration of skilled labour, a rapid decline in gross domestic product, extreme reductions in people willing to invest their money in Zimbabwe, increased illegal activities, externalisation of foreign currency, a crippled healthcare sector, a weakened school system, a poorly performing water and sanitation services sector, intensified occurrences of waterborne diseases such as cholera and typhoid, raised levels of unemployment, reduced food production, increased political instability, intensified corruption, as well as numerous other problems (Hove \& Gwiza 2012; Sachikonye 2009).

Because of the economic and financial crises faced in Zimbabwe, largely because of the trade embargoes levied against it, no dam and safety assessments were made in a lengthy period of time, for example. Water supply and wastewater treatment plants and related resources therefore 
have existed in a state of ruin and disuse (Davis \& Hirji 2014). A good example is the Kariba Dam, which is in a state of disrepair and in dire need of refurbishment. As a result of the state of disrepair of the Kariba Dam, there have been negative impacts on the ability of the hydroelectric power generators situated at Kariba Dam to generate electricity. This, in turn, has had negative impacts on water supplies in Zimbabwe, as electricity is needed to pump water to consumers, as well as to operate some of the machinery used in the sanitation of water.

According to Masaka (2012:66), in light of the segregation faced by Zimbabwe from the so-called global village, Zimbabwe's Reserve Bank felt that it was left with no alternative but to print the local currency in excess amounts. This led to the worsening of Zimbabwe's economic situation, with Zimbabwe experiencing the worst inflation rates ever experienced by a nation not at war, which exacerbated an already dire humanitarian crisis. In March 2007, Zimbabwe for the first time ever surpassed the global rating for hyperinflation. Inflation in Zimbabwe rose rapidly, reaching an all-time high at a shocking level of 79.6 billion per cent by mid-November 2008 (Hanke 2008:9). High inflation levels have continued to have a negative ripple effect on Zimbabwe's water sector even up to present times. Some of these negative effects include a lack of capital by Zimbabwean government to fund the water sector, a lack of capital to reward labour in Zimbabwe's water sector, a lack of liquidity and foreign currency to import machinery and parts vitally needed to maintain the equipment used in the distribution of water services as well as failure to purchase the chemicals necessary for the purification of water, which are imported from foreign countries such as China - amidst many other challenges.

Sanctions targeted at Zimbabwe have led to a large decline in its capital inflows (Nkomazana \& Tambudzai 2009:7). The result has been a shortage of much-needed foreign currency reserves coupled with reduced foreign investment. Reduced investment levels in Zimbabwe have negatively affected its capacity to generate electricity, water supply services and railway services (Kaminski \& Ng 2011:80). As mentioned earlier, electricity is needed to power the pumps that supply water, and railway services contribute immensely towards the water services sector as they are used to transport imported machinery that is used in this sector. Foreign currency shortages result in various challenges, such as the current brain drain in Zimbabwe's water services sector. Zimbabwe's weakening economy has resulted in skilled labour being lost to external markets as workers leave Zimbabwe in pursuit of better wages in foreign countries.

The sharp decline in the level of capital revenue in Zimbabwe that precipitated from the 1990s and has been perpetuated until this present century has resulted in the reduction of water supply levels from 79\% in 1990 to $77 \%$ in 2015 . These declines have had an impact on the whole water services sector in Zimbabwe, which negatively affects the management of the water services sector and its progress. As a result, the quality and reliability of water services in Zimbabwe have dropped dismally (Ahmad et al. 2016:1). In 2008-2009, there were cholera outbreaks in Zimbabwe, which led to 98592 people affected and 4282 deaths as a result of the state of collapse of the water services sector in Zimbabwe (United Nations Office for the Coordination of Humanitarian Affairs [UNOCHA] 2009).

\section{Commercialisation of water in Zimbabwe and its effects on the poor}

The commercialisation of the water sector in Zimbabwe started in 1998 with the passing of the 1998 Water Act, which led to water being regarded as an economic good (Government of Zimbabwe 1998b). This means that from 1998 onwards, water in Zimbabwe was no longer considered a social good that could be accessed freely by anyone. According to the Poverty Atlas, in 2011-2012, 72.3\% of all Zimbabweans were considered poor, $62.6 \%$ of households were deemed poor and out of the whole populace, $22.5 \%$ were living in dire poverty (United Nations Economic Commission for Africa 2017:viii). In Zimbabwe, it is also calculated that $88 \%$ of the poverty-stricken residents reside in rural areas, and at the same time, $31 \%$ of the entire population in the rural areas is categorised as living in poverty (Cavendish 2000:3; World Bank 1996). In 2014, Zimbabwe had an unemployment rate of $85 \%$ (Rusvingo 2015), which increased to $95 \%$ in 2019, which is viewed as the highest in the world (Mazikana et al. 2019:2). With such extreme levels of poverty in Zimbabwe, it is hard to envision how the majority of the population is expected to have the ability to afford paying for water services under the commercialisation of the water sector in Zimbabwe.

According to Chikwanha-Dzenga (1999:41), a large part (70\%) of the total populace of Zimbabwe resides in rural locations, which are dry, arid and mainly devoid of any economic productivity. Access to land, water, credit and energy is largely absent in these rural areas. The main asset for redistribution in Zimbabwe would be land and, consequently, water. A small minority of Zimbabwe's population that have been resettled since 1980 have experienced worsening living conditions caused by the absence of essential services provision and lack of water specifically. Inadequate access to water in urban and rural areas of Zimbabwe has been a challenge even before the Covid-19 pandemic (Dzirutwe 2020; Kingsley \& Moyo 2019; Mbugua 2019). Most resettled communal farmers are relocated onto land on previously solely white-owned commercial farms where no provision is made for them to be able to utilise water resources. Colonial laws, such as the Water Act of 1976, did not offer provisions enabling non-white people to access water services the same way that white people could. In present days, even under the commercialisation of water services in Zimbabwe, the situation has been perpetuated as resettled communal farmers cannot access water that flows into privately owned dams on these commercial farms (Chikwanha-Dzenga 1999:48).

Because of deteriorating economic conditions in Zimbabwe, people are now forced to earn petty wages. The wages earned by employees are so low that the majority of workers cannot afford to pay for basic services such as water. 
Employers frequently underpay workers; for example, employees may be paid $\$ 26$ a month for up to as many as eight consecutive months, whereas their basic monthly wage would be $\$ 342$ (Muchichwa 2016:12). An employee would be earning $\$ 26$, whereas they have to pay rent for a one-roomed dwelling space in the city averaging $\$ 60$ a month, electricity averaging $\$ 30$, water averaging $\$ 15$ and transport averaging $\$ 22$. As a result, one can clearly see that even urban employees cannot afford to pay for basic services in Zimbabwe, including water.

By 2008, Zimbabwe had been experiencing 12 consecutive years of economic turmoil. Zimbabwe's economy shrunk by over $51 \%$ from 1999 to 2008. Hyperinflation rose steeply to 231.2 million per cent by the second half of 2008, accompanied by long-term foreign currency deficiencies, water shortages, power outages, shortages in fuel as well as shortages in the availability of basic commodities. Industrial productivity declined significantly, salaries were eroded by inflation to the point of being rendered utterly useless and unemployment rose together with the informalisation of the economy (Muchichwa 2016:32). Hyperinflation meant that even the urban employed were rendered poor and could not afford to purchase essential goods such as water with their meagre salaries. Unemployment for the majority of the Zimbabwean citizens meant that they had no money at all to pay for water services.

According to Kemerink-Seyoum et al. (2017:425), the Zimbabwean government experienced continued fiscal deficits because of declining economic conditions. These fiscal deficits gave the state no other option except to transfer the majority of the financial burden and oversight for water services in irrigation schemes in the rural areas of Zimbabwe to poor rural communal farmers who had initially been meant to benefit from these schemes (Bolding 2004; Zawe 2006). This happened despite the fact that these poor rural communal farmers had been paying water maintenance fees for many decades prior to this, and were now being tasked with covering the expenses involved in sustaining these schemes, notwithstanding the costs accrued via the access of water from dams, as well as electricity bills that were incurred from water pumping stations. These commercialisation policies meant that communal farmers forfeited the prior investments they had made into rural irrigation projects, and have been left in a situation where they are forced to pay for various operational and management costs as well.

Table 1 presents the level of access to improved sources of drinking water in Zimbabwe in 2014 (United Nations Children's Fund [UNICEF] 2018:4).

Table 2 demonstrates the level of water supply from 1990 to 2008 in Zimbabwe. According to the World Bank (2011:10), the total water supply in Zimbabwe was 78\% in 1991, 46\% in 2008 and the government aimed to reach $100 \%$ water supply by 2015 . The figure indicated in the table for 2015 was a target set by the government as the data in Table 2 were aggregated before 2015.

Using the data from Tables 1 and 2, a graph can be plotted that shows the level of access to water in Zimbabwe from 1990 to 2014. Figure 1 aims to demonstrate how access to water in Zimbabwe for the ordinary citizen has declined over time, even during the period that the water sector in Zimbabwe was commercialised (1990-2014).

The data in Figure 1 suggest that the level of access to water in Zimbabwe has declined from 1990 to 2014. In 1990, as shown in Table 2, 78\% of the Zimbabwean population had access to a basic water supply. In 2008, as shown in Table 1, access to water supply decreased by $32 \%-46 \%$ of people having access to a basic water supply. In 2014, access to water supply increased by $30.1 \%-76.1 \%$, as shown in Table 1 . There was basically a decrease, although small, from 1990 to 2014 , in access to water supply, with $78 \%$ of the population in

TABLE 1: Access to improved sources of drinking water.

\begin{tabular}{|c|c|c|c|c|c|c|c|}
\hline Indicator & Total $(\%)$ & Rural (\%) & Urban $(\%)$ & Best province $(\%)$ & Best province & Worst province $(\%)$ & Worst province \\
\hline Improved sources of drinking water & 76.1 & 67.5 & 98.4 & 98.9 & Bulawayo & 64.3 & Masvingo \\
\hline $\begin{array}{l}\text { Improved drinking water sources and } \\
\text { improved sanitation }\end{array}$ & 29.7 & 23.1 & 46.9 & 54.7 & Bulawayo & 17.5 & Mat North \\
\hline Open defaecation & 31.7 & 43.5 & 1.1 & 0.1 & Harare & 69.6 & Mat North \\
\hline $\begin{array}{l}\text { Percent of children whose last stools } \\
\text { were disposed of safety }\end{array}$ & 57 & 46.9 & 86 & 84.8 & Harare & 19.8 & Mat North \\
\hline
\end{tabular}

Source: Based on United Nations Children's Fund (UNICEF), 2018, Water, Sanitation and Hygiene (WASH) 2018 budget brief, April 2018, UNICEF, Zimbabwe.

TABLE 2: The level of water supply in Zimbabwe (1990-2008).

\begin{tabular}{|c|c|c|c|c|c|c|c|c|c|c|c|}
\hline \multirow[t]{2}{*}{ Variable } & \multicolumn{2}{|c|}{ Coverage } & \multirow{2}{*}{$\begin{array}{c}\text { Target } \\
2015(\%)\end{array}$} & \multirow{2}{*}{$\begin{array}{l}\text { Population } \\
\text { requiring } \\
\text { access: } \\
\text { ‘000 per year }\end{array}$} & \multicolumn{2}{|c|}{ CAPEX requirements } & \multicolumn{3}{|c|}{$\begin{array}{l}\text { Anticipated public CAPEX } \\
\text { (US\$ million per year) }\end{array}$} & \multirow[t]{2}{*}{$\begin{array}{l}\text { Assumed HH } \\
\text { CAPEX }\end{array}$} & \multirow[t]{2}{*}{$\begin{array}{l}\text { Total } \\
\text { deficit }\end{array}$} \\
\hline & $1990(\%)$ & $2008(\%)$ & & & Total & Public & Domestic & External & Total & & \\
\hline Rural water supply & 70 & 40 & 100 & 757 & 174 & 157 & 6 & 33 & 39 & 4 & 131 \\
\hline Urban water supply & 97 & 60 & 100 & 374 & 369 & 148 & 20 & 34 & 54 & 81 & 234 \\
\hline Water supply total & 78 & 46 & 100 & 1131 & 544 & 305 & 26 & 67 & 93 & 85 & 365 \\
\hline Rural sanitation & 35 & 25 & 80 & 686 & 90 & 45 & 2 & 12 & 14 & 14 & 62 \\
\hline Urban sanitation & 99 & 40 & 100 & 483 & 325 & 227 & 11 & 25 & 36 & 15 & 273 \\
\hline Sanitation total & 54 & 30 & 85 & 1124 & 415 & 272 & 13 & 37 & 50 & 29 & 336 \\
\hline
\end{tabular}

Source: Based on World Bank, 2011, Water supply and sanitation in Zimbabwe: Turning finance into services for 2015 and beyond. An AMCOW country status overview, World Bank, Nairobi, viewed 23 November 2020, from https://openknowledge.worldbank.org/handle/10986/17762. 


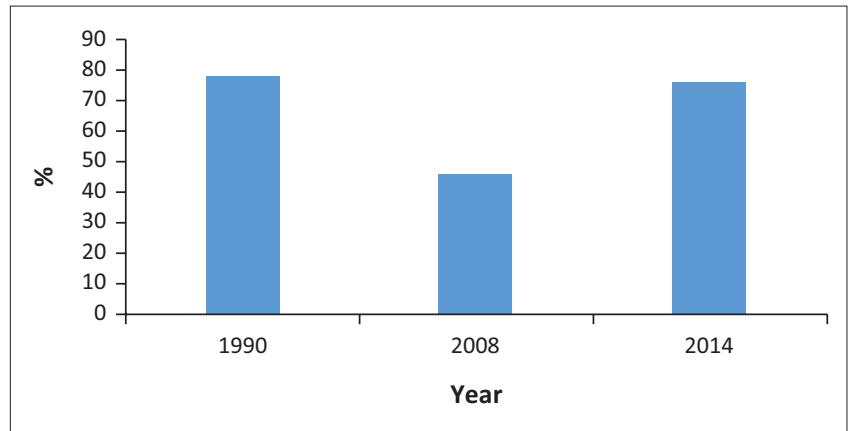

FIGURE 1: Access to water in Zimbabwe (1990-2014).

1990 having access to a basic water supply as compared to $76.1 \%$ in 2014.

There are challenges with the efficiency of revenue collection under the commercialisation of the water services sector in Zimbabwe. There were decreases in the efficiency of revenue collection, which fell from $52 \%$ in 2012 to $41 \%$ in 2013 . This has occurred in a situation where there is a shortage of money in circulation in Zimbabwe because of inflation, coupled with shortages of foreign currency. This has been made worse by the fact that water users generally do not want to pay for water services in Zimbabwe - an attitude that is reinforced by frequent debt cancellations of water arrears by the Zimbabwean government, such as those that were made in 2013.

Municipalities in Zimbabwe also cannot manage their water billing systems very well, with some city councils writing down the payments made by consumers for water services as arrears on their accounts (Muyambo \& Klaassen 2015:22). Because of this circumstance, the poor have no other recourse but to repeatedly pay for the same amount of water they have already used, which further depletes their already meagre wages.

According to Makwara and Tavuyanago (2012:164), the majority of urban areas in Zimbabwe have old and outdated water services infrastructure. Old pumps and motors mean that urban municipalities fail to provide water services. Water treatment works are outdated and do not function properly. People living in high-density areas, the majority of whom are poor, are forced to go without water for long periods of time as municipalities fail to raise the revenue to replace old infrastructure. Old and faulty infrastructure results in highlying urban areas not receiving water because of old and ineffective pumping infrastructure, which results in weak water flow. Even if municipalities were to increase the tariffs, the residents would not have the money to pay. Even if residents were to pay, in the presence of inflation, the money collected would decrease in value, which means that it would be rendered useless by the time it must be used by municipalities. Under these prevailing conditions, municipalities are unable to replace and service old infrastructure.

Urbanisation has been increasing rapidly in developing countries and Zimbabwe is no exception. Rapid rates of urbanisation in developing countries, such as Zimbabwe, have continuously overwhelmed the capacity of municipalities to provide sufficient basic services, such as water. Access to clean water in Zimbabwean cities has been greatly reduced, especially from 2006 to 2008 (Makwara \& Tavuyanago 2012:171). Urbanisation in Zimbabwean cities is mainly concentrated in informal settlements and high-density areas that are mostly populated by the poor. Because of an ailing economy and a severe cash crunch in Zimbabwe, municipalities have continued to fail to raise the revenue required to further develop existing water services infrastructure in order to meet the growing demand for water, which is spurred on by rapid urbanisation. This has resulted in residents - particularly the poor - in urban areas being left without access to basic services such as the provision of water.

\section{Poverty and access to water: A case study of Zimbabwe}

According to Serumaga-Zake, Kotze and Madsen (2005), Chakravarty, Deutsch and Silber (2008) and Abotutu (2014), poverty can be defined as resulting from a lack of decent living and a relative lack of access to bare necessities that include clean water, electricity, education, a balanced diet and healthcare. Poverty has also been defined as a situation in which a person or people have limited power over tangible resources or lack adequate money to purchase the required bare necessities universally accepted as being crucial for an individual to live a normal life (Gelderblom 2007; Mears \& Blaauw 2010). According to the World Bank (1996:8), an estimated 25\% of the population in Zimbabwe were poor in 1990. In 2008, poverty rates in Zimbabwe increased to more than $72 \%$, rendering $20 \%$ of the total populace to be classified as living in dire poverty (Rodgers 2018). In 2011, 22.5\% of the population in Zimbabwe lived in poverty, which rose to $30.4 \%$ in 2017, and further increased to $38.3 \%$ in 2019 (World Bank 2019).

Using the data above, Figure 2 seeks to illustrate the changes in poverty levels in Zimbabwe from 1990 to 2019.

The data in Figure 2 indicates that poverty levels in Zimbabwe rose from 1990 until 1998 when the water sector in Zimbabwe was commercialised. Poverty levels in Zimbabwe continued to rise after the commercialisation of the water sector in 1998 and reached a peak in 2008. Poverty levels in Zimbabwe dropped to $22.5 \%$ in 2011 but rose again to $38.3 \%$ in 2019 . Eleven years after the commercialisation of the water sector in Zimbabwe, almost $40 \%$ of its population still lives in poverty. This suggests that the commercialisation of the water sector in Zimbabwe did little to reduce poverty levels. The suggestion from Figure 2 is that by 2019, the commercialisation of the water sector in Zimbabwe meant that $38.3 \%$ of the population in Zimbabwe struggled to pay for water because of poverty.

The commercialisation of the water sector has led to increased inequality in Zimbabwe. The commercialisation of water has meant that the wealthy, who can afford to pay for water, continue to access water in large quantities as they can afford 


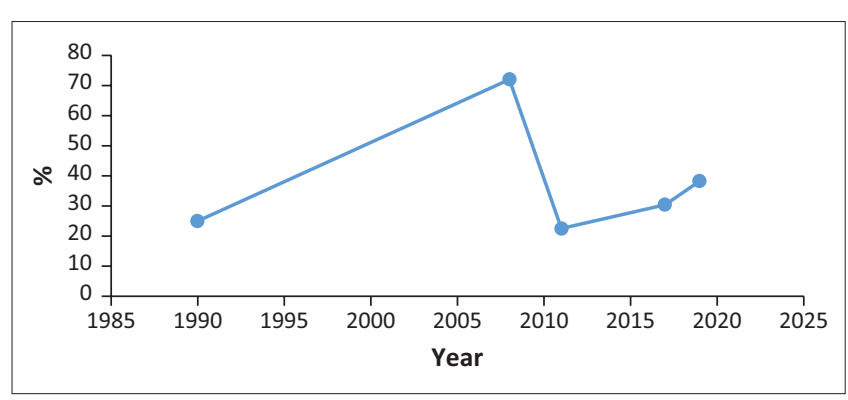

FIGURE 2: Poverty levels by percentage over time in Zimbabwe.

to do so. The wealthy therefore overuse water, which depletes ground reserves and dries up aquifers, by filling their swimming pools, watering their gardens and pursuing various industrial endeavours. As a result, the wealthy deplete and pollute large quantities of water at the expense of the poor. This occurs in a situation where the poor in Zimbabwe continue to access fewer water resources because of increasing tariffs, which are worsened by inflation, declining economic conditions and shortages of basic commodities. Pricing mechanisms often negatively impact the poor to a greater extent than they do to the wealthy, and therefore the poor will have less access to water as a result of the commercialisation of water (Makwara \& Tavuyanago 2012:172).

The commercialisation of the water services sector in Zimbabwe has resulted in a situation whereby the poor are not given a platform to participate in the administration of water services. This is typically exemplified in the resettlement of rural communal farmers onto previously white-owned commercial farms where the newly resettled communal farmers are not given access to the water resources that are found on these farms. This is evidence of the absence of provisions or platforms whereby communal farmers can participate in water legislation, or express the challenges that they face. Commercialisation has merely been addressed on the basis of the government seeking to raise revenue whilst in the same context failing to foster the relevant participation of all stakeholders, particularly the poor (Mtisi 2011:20)

According to Mapfumo and Madesha (2014:3), Zimbabwe experienced its worst cholera epidemic, with almost 5000 out of about 83631 people who were infected dying - this number includes children. The cholera outbreak was almost inevitable considering the challenges that were faced in the water services sector in Zimbabwe. Multiple households in the cities and rural areas of Zimbabwe underwent extended time periods where they had no clean water nor decent sanitation services. The inability of the water services sector to raise funds for the provision of clean water under commercialisation was partly to blame. This led to the spread of water-related diseases such as cholera, which mostly affected the poor who could not afford to drill boreholes on their own land, if they had any land in the first place, to find alternative water sources, nor had they the money to seek adequate medical assistance in the case of being infected with water-related illnesses.
Gender inequality in Zimbabwe mostly occurs amongst the poor and is worsened by the inability to access bare necessities that include water, for instance (Colclough et al. 1990:16). Poor families in Zimbabwe do not have enough money to enrol all of their children in school and opt to send boys instead of girls. The commercialisation of the water sector in Zimbabwe means that what little money poor families would have used to send girls to school is used instead to pay for water bills. It is of vital importance that people have access to safe water as well as sanitation as this enhances access to education and reduces absenteeism and dropout rates (Noga \& Wolbring 2012:3025).

The time spent in collecting water has debilitating effects on the well-being of women and children (Graham, Hirai \& Kim 2016:2). Less time spent in fetching water by women gives them a higher amount of time that they do not have to do any work, amounting to at least 48 extra free minutes per $24 \mathrm{~h}$ (Cairncross \& Cliff 1987). The more time spent by women resting enables them to spend more time with their children or more time doing school work, socialising or other developmental endeavours. The risk of being sexually violated and the psychological turmoil accompanied with that risk is heightened when women are forced to go long distances to fetch water. The commercialisation of water in Zimbabwe means that the poor may be unable to pay for water, and women and children from poor families are therefore forced to travel long distances to fetch water, in which case these women and children are more vulnerable to sexual violence.

According to Noga and Wolbring (2012:3024), water is essential for sustainable development and safeguarding the environment, as well as reducing global poverty and hunger. Water is also vital in ensuring human health and well-being. The need for people to have access to clean, reliable and inexpensive water and sanitation is crucial for sustainable development and effectively reducing poverty. Limited access to water and sanitation for poor communities heightens their living expenses, reduces their earnings, negatively impacts their health and makes their life riskier (ed. Jeni 2002). In Zimbabwe before 2000, commercial farm workers and their dependants, who were mostly black, were largely impoverished and suffered reduced employment and nutritional security, increased infant malnutrition, lack of access to decent living conditions and lack of access to water sanitation, medical services and education (Kinsey 2010:5). The commercialisation of water in Zimbabwe will surely result in a situation where the spatial distribution of poverty in Zimbabwe amongst the majority black population will persist.

There are large discrepancies in income and wealth distribution in Zimbabwe (Kinsey 2010:5). In the early 1990s, more than half of the population shared just $15 \%$ of the overall income, whilst the wealthiest 3\% earned 30\% of the overall income (Stenflo 1993). Zimbabwe's Gini coefficient in the 1990s was as high as 0.57 (Killick, Carlsson \& Kierkegaard 
1998). The high levels of inequality in the 1990s were because of the highly unequal ownership of agricultural land and water resources. During the 1990s, about 4000 farms that were mostly commercially owned and operated on a large scale took most of the land space in Zimbabwe.

The majority of the owners of these commercial farms were white farmers and these farms were frequently located on the most fertile land that happened to also receive the most rainfall. As a result, the Gini coefficient for inequality amongst people was higher in rural areas than in urban areas. The commercialisation of the water sector in Zimbabwe will most likely result in the perpetuation of inequality in wealth and income distribution. Poor communal farmers will be left without access to water for their crops because of a lack of funds to purchase water and, as a result, will have no harvest and remain in poverty or likely fall into more debt as they might borrow money from banks to pay for water services and other inputs.

\section{Conclusion and recommendations}

The right to access water is a basic human right as legislated by the United Nations, of which Zimbabwe is a member. The Constitution of Zimbabwe Amendment Act (No. 20 of 2013) (Government of Zimbabwe 2013) also ensures access to water as a basic right for all citizens. The government of Zimbabwe therefore needs to ensure that despite whatever policy is put in place, the right to free basic water supply must be ensured for all citizens, without discrimination. The Government of Zimbabwe must therefore ensure that every citizen receives a basic water allocation that is necessary for survival and basic human requirements. Such a provision needs to be clearly stated in the legislation and the necessary mechanism to enable its implementation provided for. A good example is the free basic water policy in South Africa.

Whatever legislation is put in place to govern the distribution of water in Zimbabwe must take into account historical narratives pertaining to water distribution in Zimbabwe. Considering the fact that the majority of Zimbabwean citizens were historically excluded from access to Zimbabwe's water resources, there is a need to consider that service extension must be a priority. Present-day circumstances and environments must also be considered when putting a water management policy in place. For example, in land distribution, there is a need to ensure that the poor are not forgotten with regard to access to water. There is also a need to take into consideration current economic challenges and how they impact consumers' ability to pay for water services.

There is a need to also ensure that there is relevant and adequate participation of all stakeholders involved in the water services sector in the making of water policy in Zimbabwe. The exclusion of newly resettled black communal farmers from water access on previously white-owned commercial farms suggests that the poor and previously disadvantaged in Zimbabwe are not being given an adequate platform to participate in water policymaking decisions. The participation of all involved stakeholders will enable the adoption of water policies that are holistic and responsive to local needs, and at the same time supportive of the principles of a developmental state. Enabling stakeholders to participate in policymaking also enhances their support of and commitment towards government policies.

\section{Way forward}

There needs to be better education in terms of water service provision and the issues involved therein. If public servants are better educated, then they will better serve consumers through effective policymaking. If consumers are better educated, then they can more effectively participate in water service delivery issues and thus improve their own circumstances. A more informed consumer space will be able to use the right and legal channels to communicate their grievances to government as well as to more effectively participate in the solutions that are brought forward. A better educated society in any circumstance is in a better situation to solve its problems using peaceful and progressive means.

There needs to be a higher level of integration and cooperation between all the stakeholders involved in water services. Integration and cooperation will enable all the stakeholders to come together and combine their resources that will result in more effective outcomes. For example, the public sector can provide the legal spaces, policy guidelines as well as capital. The non-governmental sector can contribute expertise, technology and resources that are otherwise not available to the government. The consumer space can contribute local indigenous knowledge, and by owning and accepting projects implemented by other stakeholders, the consumer sector can better take care of the resources that are meant to benefit them and use these resources efficiently.

Increased monitoring and evaluation in the water sector will go a long way to ensure that there is sustainability and effectiveness in policy processes. This can be achieved by encouraging experts from, for example, universities, nongovernmental organisations and other sectors to analyse and evaluate policy processes. Monitoring and evaluation will also enable the achievements made and the challenges experienced to be more effectively identified and remedied, enabling service delivery enhancement both in the short term and long-term period. Funding can also be made available for higher levels of research focused towards the water services sector that will enhance the available knowledge regarding the achievements made and the challenges faced in the water services sector.

There is a need to emphasise sustainable water use in the water services sector. Commercialisation in the water sector must be approached with caution as it may allow the rich to over-exploit water resources based on the virtue that the rich have enough money to pay for excessive water usage. Legislation guiding water use must take into consideration other aspects such as sustainable resource usage, equal access and promotion of basic human rights. Legislation should not 
only focus on profit making at the expense of environmental pollution and sustainable development. Water usage should thus be monitored to ensure that water resources are not over-exploited.

Access to information regarding water services must be made more readily available and accessible. When society has better access to information, it is in a better position to assert and insist on sustainable resource use. With better access to information, consumers, for example, are in a better position to use water more wisely, thus conserving water, reducing pollution, increasing sustainability and helping to eradicate poverty. Better access to information means that consumers are also in a better position to contribute towards government initiatives aimed at enhancing water services.

Benchmarking should be practised in the water services sector. Benchmarking enables comparisons to be made with other case studies and facilitates learning experiences to be made from observing other case studies and their efforts towards solving their own water crises. This would facilitate the avoidance of making similar unnecessary mistakes that other case studies have made in attempting to solve their own water problems. By so doing, water service authorities would be able to save much precious time and money, whilst at the same time providing better water services.

Water services authorities must implement integrated water resource management. Integrated water resource management involves implementing both supply and demand side management of water resources instead of over-emphasising the application of any single method at the expense of the other. The majority of water service providers over-emphasise the application of supply side interventions to water services whilst neglecting demand side interventions. Ironically, supply side interventions are often costly, have limited application and are mostly unsustainable. For example, there is limited space to build dams and lakes, and it is also very expensive to construct large canals. On the other hand, demand side interventions such as reducing water consumption by better detecting and repairing water leaks result in less water lost before it reaches the consumer and cost much less to implement. This results in less water charges for all consumers, including the poor, thus helping to reduce poverty and encourage more sustainable environments whilst fostering development as less water is pumped into the system, thus conserving the precious mineral.

\section{Acknowledgements}

This article was submitted as part of the requirements for fulfilling the conditions for attaining a $\mathrm{PhD}$ qualification at the University of Johannesburg in South Africa. The author would like to acknowledge the University of Johannesburg for providing the time and resources necessary in order to complete this article.

\section{Competing interests}

The authors have declared that no competing interest exists.

\section{Authors' contributions}

T.M. contributed to the conceptualisation, methodology, formal analysis, investigation, writing of original draft, project administration, validation, data curation, resources, review, editing and writing of the article. D.U. contributed to the conceptualisation, methodology, formal analysis, investigation, writing of original draft, project administration, validation, data curation, resources, review, editing, writing, funding acquisition and supervision of the article. D.N-S. contributed to the conceptualisation, methodology, formal analysis, investigation, writing of original draft, project administration, validation, data curation, resources, review, editing, supervision and funding acquisition of the article.

\section{Ethical considerations}

This article followed all ethical standards for research without direct contact with human or animal subjects.

\section{Funding information}

This research received no specific grant from any funding agency in the public, commercial or not-for-profit sectors.

\section{Data availability}

The authors confirm that the data supporting the findings of this study are available within the article.

\section{Disclaimer}

The views and opinions expressed in this article are those of the authors and do not necessarily reflect the official policy or position of any affiliated agency of the authors.

\section{References}

Abotutu, A.A., 2014, 'Urbanization and poverty in the Third World: Measurement, patterns and policies in Warri Metropolis, Nigeria', African Review of Science and Technology 3(1), 220-246, viewed 07 June 2021, from https://www.ajol.info/ index.php/stech/article/view/103133.

Ahmad, T., Kinyanjui, V., Jonga, M. \& Mashingaidze, H.R., 2016, Public private partnership for rural water supply: Experiences from Zimbabwe, viewed 12 January 2021, from https://rwsnforum7.files.wordpress.com/2016/11/5b_4 lovemore_zimbabwe_final.pdf.

Blomgren, A., 1997, Neo-liberal political philosophy: A critical analysis of Milton Friedman, Robert Nozick and Frederick Hayek, transl. T.D. Einar, Bokförlaget Press, Nora.

Bolding, A., 2004, 'In hot water: A study on socio-technical intervention models and practices of water use in smallholder agriculture, Nyanyadzi catchment, Zimbabwe', PhD thesis, Wageningen University, viewed 07 June 2021, from https://edepot.wur.nl/164902.

Burgin, A., 2012, The great persuasion: Reinventing free markets since the Depression, Harvard University Press, Cambridge, viewed 07 June 2021, from http://www. jstor.org/stable/j.ctt2jbpjh.

Cairncross, S. \& Cliff, J.L., 1987, 'Water use and health in Mueda, Mozambique', Transactions of the Royal Society of Tropical Medicine and Hygiene 81(1), 51-54. https://doi.org/10.1016/0035-9203(87)90280-x

Cavendish, W., 2000, 'Empirical regularities in the poverty-environment relationship of rural households: Evidence from Zimbabwe', World Development 28(11), 19792003. https://doi.org/10.1016/S0305-750X(00)00066-8

Chakravarty, S.R., Deutsch, J. \& Silber, J., 2008, 'On the Watts multidimensional poverty index and its decomposition', World Development 36(6), 1067-1077, viewed 07 June 2021, from https://www.econstor.eu/bitstream/10419/192774/1/ dp792.pdf.

Chikwanha-Dzenga, A.B., 1999, 'Rural folks: The neglected Lot of Zimbabwe', Journal of Social Development in Africa 14(2), 39-49, viewed 07 June 2021, from https:// www.africabib.org/htp.php?RID=189780428. 
Colclough, C., Lofstedt. J.I., Manduvi-Moyo, J., Maravanyika, O.E. \& Ngwata, W.S. 1990, Education in Zimbabwe: Issues of quantity and quality, Swedish International Development Authority, Stockholm, viewed 07 June 2021, from https:// publikationer.sida.se/contentassets/0f4632bccb7f4b6eb459c132715c4c58/ publikationer.sida.se/contentassets/0f $4632 \mathrm{bccb} 7 \mathrm{f} 4 \mathrm{~b} 6 \mathrm{eb} 459 \mathrm{c}$

Crouch, C., 2011, The strange non-death of neo-liberalism, Polity Press, Cambridge.

Davies, W., 2014, 'A bibliographic review of neoliberalism', Journal of Theory, Culture and Society 31(7), 309-317. https://doi.org/10.1177/0263276414546383

Davis, R. \& Hirji, R., 2014, Climate change and water resources planning, developmen and management in Zimbabwe: An issues paper, World Bank, Washington, DC, viewed 07 June 2021, from http://hdl.handle.net/10986/24096.

Derman, B., Ferguson, A. \& Gonese, F., 2000, Decentralisation, devolution and development: Reflections on the water reform process in Zimbabwe - Broadening access and strengthening Input Systems Collaborative Research Programme (BASIS, CRSP), viewed 13 January 2021, from http://crsps.net/wp-content/ downloads/BASIS/Inventoried\%2010.19/13-2000-7-594.pdf.

Dzirutwe, M., 2020, 'Families trek to unsafe wells as taps run dry in drought-hit Zimbabwe', Reuters, 27 January, viewed 07 June 2021, from https://www.reuters. com/article/us-climate-change-zimbawe-water-idUSKBN1ZQOIM

Economic Consulting Associates Limited, 2011, Zimbabwe urban water tariff study: Final report, December 2011, Economic Consulting Associates Limited, London,
viewed 07 June 2021, from http://documents1.world bank.org/curated/ viewed 07 June 2021, from http://documents1.world bank.org/curated/ urban-water-tariffs-Final-Final-Report-Dec-2011.pdf.

Friedman, M., 1962, Capitalism and freedom, University of Chicago Press, Chicago, IL.

Gane, N., 2013, 'The emergence of neoliberalism: Thinking through and beyond Michel Foucault's lectures on biopolitics', Theory, Culture and Society 31(4), 3-27. https://doi.org/10.1177\% 2F0263276413506944

Gelderblom, D., 2007, 'Does poverty constrain migration in South Africa? Evidence, explanations and implications', Development Southern Africa 24(2), 241-255. https://doi.org/10.1080/03768350701327152

Government of Zimbabwe, 1998a, Zimbabwe National Water Authority Act (ZINWA), No. 11 of 1998, Government Printer, Harare.

Government of Zimbabwe, 1998b, Water Act, No. 31 of 1998, Government Printer Harare, viewed 07 June 2021, from https://zimlii.org/zw/legislation/numact/1998/31/WATER\%20ACT\%20.pdf.

Government of Zimbabwe, 2013, Constitution of Zimbabwe Amendment Act, No. 20 of 2013, Government Printer, Harare. https://www.constituteproject.org/ constitution/Zimbabwe_2013.pdf

Graham, J.P., Hirai, M. \& Kim, S.S., 2016, 'An analysis of water collection labor among women and children in 24 sub-Saharan African countries', PLoS One 11(6), 1-14. https://doi.org/10.1080/09502386.2011.619886

Hall, S., 2011, 'The neoliberal revolution', Cultural Studies 75(6), 705-728. https://doi org/10.1080/09502386.2011.619886

Hanke, S., 2008, Zimbabwe: From hyperinflation to growth, Cato Institute, Washington, DC. Harvey, D., 2005, A brief history of neoliberalism, Oxford University Press, Oxford.

Hayek, F.A., 1979, Law, legislation and liberty: A new statement of the liberal principles and political economy, Vol. III: The political order of a free people, Routledge, London.

Hölscher, D., 2018, 'Caring for justice in a neoliberal university: The ethics of care and academic development', South African Journal of Higher Education 32(6), 31-48. https://doi.org/10.20853/32-6-2676

Hove, M. \& Chingono, H., 2013, 'National interests and the sanctions strategy 19592013', Review of History and Political Science 1(1), 1-17.

Hove, M. \& Gwiza, A., 2012, 'The Fast-Track Land Reform Programme and food insecurity: A case of Zimbabwe from 1992 to the present', American International insecurity: A case of Zimbabwe from 1992 to the present', American International
Journal of Contemporary Research 2(8), 282-293, viewed 07 June 2021, from Journal of Contemporary Research 2(8), 282-293, viewed 07 June
http://www.aijcrnet.com/journals/Vol_2_No_8_August_2012/28.pdf.

Jeni, K. (ed.), 2002, A sourcebook for poverty reduction strategies, vol. 2 Macroeconomic and sectoral approaches, World Bank Group, Washington, DC.

Kaminski, B. \& Ng, F., 2011, Zimbabwe's foreign trade performance during the decade of economic turmoil: Will exports recover? A revised version of a background (AFTP1), viewed 06 January 2020, from http://siteresources.worldbank (AFTP1), viewed O6 6461208-1300202947570/Zimbabwe_Trade_Diagnostic.pdf.

Kanyongo, D.E., 2016, 'Targeted sanctions as a new political discourse in Zimbabwe: A transition or obstacle to democracy from 2000-2013', Master's thesis, University of KwaZulu-Natal.

Kemerink-Seyoum, J.S., Chinguno, N.L.T., Seyoum, S.D., Ahlers, R., Bolding, J.A. \& Van der Zaag, P., 2017, 'Jumping the water queue: Changing waterscapes under water reform processes in rural Zimbabwe', Water SA 43(3), 423-422. https://doi. org/10.4314/wsa.v43i3.07

Killick, T., Carlsson, J. \& Kierkegaard, A., 1998, European aid and the reduction of poverty in Zimbabwe, Working paper 109, Overseas Development Institute, London, viewed 07 June 2021, from https://www.odi.org/sites/odi.org.uk/files/ odi-assets/publications-opinion-files/7044.pdf.

Kingsley, P. \& Moyo, J., 2019, 'In Zimbabwe, the water taps run dry and worsen "a nightmare"', New York Times, 31 July, viewed 07 June 2021, from https://www. nytimes.com/2019/07/31/world/africa/zimbabwe-water-crisis.html.

Kinsey, B., 2010, 'Poverty dynamics in rural Zimbabwe: The 30 years (lost) "war against poverty"', Paper for the Ten Years of War against Poverty - What Have We Learned Since 2000? Conference, Chronic Poverty Research Centre/Brooks World Poverty Institute, University of Manchester, Manchester, 08th-10th September.
Makurira, H. \& Mugumo, M., 2006, 'Water sector reforms in Zimbabwe: The importance of policy and institutional coordination on implementation', Proceedings of the African Regional Workshop on Watershed Management, Nairobi, October 2005, viewed 07 June 2021, from https://agris.fao.org/agrisNairobi, October 2005, viewed 07 June 2021.
search/search.do?recordID=XF2006426713.

Makwara, E.C. \& Tavuyanago, B., 2012, 'Water woes in Zimbabwe's urban areas in the midst of plenty: 2000-present', European Journal of Sustainable Development midst of plenty: 2000-present, European Journal of Sustainable Development V1N2/makwara\%20151-182.pdf

Manzungu, E., 2002, The process and dynamics of catchment management in Zimbabwe, Save Africa Trust Publications, Harare.

Manzungu, E., Mudenda-Damba, M., Madyiwa, S., Dzingirai, V. \& Musoni, S., 2016, 'Bulk water suppliers in the City of Harare - An endogenous form of privatisation of urban domestic water services in Zimbabwe?', Water Alternatives 9(1), 56-80.

Mapfumo, A. \& Madesha, M.W., 2014, Challenges for urban water supply: The case of Masvingo Municipality in Zimbabwe, University of Zimbabwe, Harare.

Masaka, D., 2012, 'Paradoxes in the "sanctions discourse" in Zimbabwe: A critical reflection', African Study Monographs 33(1), 49-71. https://doi.org/10.14989/ 156515

Mathekganye, J., Van Heerden, L. \& Ukwandu, D., 2019, 'The nexus between water neoliberalism and sustainable development in post-apartheid South Africa', African Journal of Public Affairs 11(3), 41-58, viewed 07 June 2021, from https:// hdl.handle.net/10520/EJC-19604996c9.

Mazikana, A.T., Peku, T., Sifile, O. \& Mudziso, R., 2019, The nexus between educated youth unemployment and youth's capacity to contribute towards wealth creation in Zimbabwe, Chinhoyi University of Technology and Zimbabwe National University of Science and Technology, Chinhoyi/Harare.

Mbiba, B., 2001, 'Communal land rights in Zimbabwe as state sanction and social control: A narrative, Africa', Journal of the International African Institute 71(3) 426-448. https://doi.org/10.3366/afr.2001.71.3.426

Mbugua, S., 2019, 'Two million in Zimbabwe's capital have no water as city turns off taps', Climate Home News, 15 July, viewed 07 June 2021, from https://www. climatechangenews.com/2019/07/15/two-million-zimbabwes-capital-no-watercity-turns-off-taps/.

Mears, R.R. \& Blaauw, P.F., 2010, 'Levels of poverty and the poverty gap in rural Limpopo', Acta Commercii 10(1), 89-106. https://doi.org/10.4102/ac.v10i1.118

Mises, L.V., 1962, The free and prosperous Commonwealth: An exposition of the ideas of classical liberalism, Van Nostrand Press, Princeton, NJ.

Mtisi, S., 2011, Water reforms during the crisis and beyond: Understanding policy and political challenges of reforming the water sector in Zimbabwe, Working pape 333: Results of ODI research presented in preliminary form for discussion and critical comment, Overseas Development Institute, London.

Muchichwa, N., 2016, Working without pay: Wage theft in Zimbabwe, Labour and Economic Development Research Institute of Zimbabwe (LEDRIZ), Harare.

Musemwa, M., 2008, The politics of water in post-colonial Zimbabwe, 1980-2007, University of the Witwatersrand, Johannesburg.

Muyambo, A. \& Klaassen, W., 2015, Capacity building for Zimbabwean urban local authorities in water supply needs assessment and business opportunities report, Netherlands Enterprise Agency, Den Haag, viewed 07 June 2021, from https:// www.rvo.nl/sites/default/files/2016/01/Final\%20report\%20Zimbabwe\%20 water\%20sector.pdf.

Nkomazana, N. \& Tambudzai, Z., 2009, 'Cause and effect analysis of the Zimbabwean foreign exchange crisis', Paper presented at the Business and Management conference at the University of KwaZulu-Natal, Durban, South Africa, 05th-07th November.

Noga, J. \& Wolbring, G., 2012, 'The economic and social benefits and the barriers of providing people with disabilities accessible clean water and sanitation', Sustainability 4(11), 3023-3041. https://doi.org/10.3390/su4113023

Nozick, R., 1974, Anarchy, state and utopia, Blackwell, Oxford.

Nyoni, T., 2019, The curse is real in Zimbabwe: Economic sanctions must go!, viewed 18 December 2019, from https://mpra.ub.uni-muenchen.de/96911/.

Ogbonna, C., 2017, 'Targeted or restrictive: Impact of US and EU sanctions on education and healthcare of Zimbabweans', African Research Review 11(3), 31-41.

Palley, T.I., 2004, From Keyensianism to neoliberalism: Shifting paradigms in economics, viewed 19 December 2019, from https://fpif.org/from_keynesianism_ to_neoliberalism_shifting_paradigms_in_economics/.

Pazvakavambwa, S., 2002, The process and dynamics of catchment management in Zimbabwe, Save Africa Trust Publications, Harare.

Phillips-Fein, K., 2009, Invisible hands: The making of the conservative movement from the New Deal to Reagan, W.W. Norton and Company, Yayasan Obor Indonesia.

Rodgers, L., 2018, 'Zimbabwe in 10 numbers', BBC News, viewed 05 January 2020, from https://www.bbc.com/news/world-africa-42013720.

Rusvingo, S.L., 2015, 'The Zimbabwe soaring unemployment rate of $85 \%$ : A ticking time bomb not only for Zimbabwe but the entire SADC region', Global Journal of Management and Business Research 14, 9-B, viewed 05 January 2020, from https://journalofbusiness.org/index.php/GJMBR/article/view/1513.

Sachikonye, L.M., 2009, The social impact of diamonds extraction in ChiadzwaMarange, Southern Africa Resource Watch, Johannesburg.

Serumaga-Zake, P., Kotze, D. \& Madsen, R., 2005, 'A descriptive study of the dynamics of relative poverty in the Western Cape province of South Africa', Development Southern Africa 22(1), 143-160. https://doi.org/ 10.1080/03768350500044610. 
Stedman-Jones, D., 2012, Masters of the universe: Hayek, Friedman and the birth of neoliberal politics, Princeton University Press, Princeton, NJ.

Stenflo, G.A., 1993, Poverty in Zimbabwe 1990-91: Report from a short-term mission to the Central Statistical Office, Harare, The World Bank, Washington, DC.

Thorsen, D.E. \& Lie, A., 2007, What is neoliberalism?, University of Oslo, Oslo.

United Nations Children's Fund (UNICEF), 2018, Water, Sanitation and Hygiene (WASH) 2018 budget brief, April 2018, UNICEF, Harare.

United Nations Economic Commission for Africa (UNECA), 2017, Country profile 2017: Zimbabwe, viewed 04 January 2021, from https://www.uneca.org/sites/ default/files/uploaded-documents/CountryProfiles/2018/zimbabwe cp eng_2017.pdf.

United Nations Office for the Coordination of Humanitarian Affairs (UNOCHA), 2009, Zimbabwe cholera update: Situation report No. 22, 15 July 2009, viewed 19 December 2020, from https://reliefweb.int/sites/reliefweb.int/files/resources/71 OBDD52303B8C47492575FA00051308-Full_Report.pdf.

Venugopal, R., 2015, 'Neoliberalism as concept', Economy and Society 44(2), 165-187. https://doi.org/10.1080/03085147.2015.1013356

Von Benda-Beckmann, F., Von Benda-Beckmann, K. \& Griffiths, A. (eds.), 2005, Mobile people, mobile law: Expanding legal relations in a contracting world, Ashgate Publishing Company, Aldershot. https://doi.org/10.4324/9781315248806
Will, G., 2003, 'Wege aus der isolation: Birmas nationaler und internationaler Aussöhnungsprozess', German Institute for International Politics and Security 36(1) 21-26, viewed 07 June 2021, from https://nbn-resolving.org/urn:nbn:de:016821-26, viewed
ssoar-262074.

World Bank, 1996, Understanding poverty and human resources in Zimbabwe: Changes in the 1990s and directions for the future-A discussion paper, The World Bank: Eastern and Southern Africa, Washington, DC.

World Bank, 2011, Water supply and sanitation in Zimbabwe: Turning finance into services for 2015 and beyond. An AMCOW country status overview, World Bank Nairobi, viewed 23 November 2020, from https://openknowledge.worldbank. org/handle/10986/17762.

World Bank, 2019, Poverty headcount ratio at national poverty lines (\% of population Zimbabwe), viewed 05 January 2020, from https://data.worldbank.org/indicator/ SI.POV.NAHC? locations=ZW.

Zawe, C., 2006, 'Reforms in turbulent times: A study of the theory and practice of three irrigation management policy reform models in Mashonaland, Zimbabwe', $\mathrm{PhD}$ thesis, Wageningen University,
wur.nl/WebQuery/wurpubs/349750.

Zimbabwe Lawyers for Human Rights, 2015, Section 77 of the Constitution: The right to safe, clean and potable water - Promoting active citizenship to defend and enforce the social and economic rights in the Constitution, Fact Sheet No. 5, The European Union, Europe, viewed 05 January 2020, from https://www.zlhr.org.zw/ wp-content/uploads/2017/01/2015-Right-to-Water.pdf. 